\title{
Rethinking the Development of US-China Relations
}

\section{Introduction}

The development of Sino-American relations has been a hot topic in world politics since the establishment of the People's Republic of China in 1949. Needless to say, the formal establishment of diplomatic relations in 1979 between the two nations have since led to ever-increasing political contact and exchange. Not only are officials, political leaders, policy-makers, and various lobby groups participating in this relationship, but many scholars in the field of International Relations have also suggested many different approaches to explain the changes and development of this relationship. Questions such as whether the United States should "contain" or "engage" China have caused serious debates in the field of International Relations. Since the fall of the Soviet Union and the success of China's economic reforms in the 1990's, such debates have only grown ever more heated.

If one examines the development of US-China relations in the past 30 years, he will find that although the relationship between China and the United States has encountered many challenges and difficulties (made painfully clear by the many disputes and crises related to trade, human rights, and national security issues), armed conflict or war has never happened between them. This seems to indicate that the pessimistic predictions and viewpoints as suggested by Realist's power politics and the democratic peace thesis are wrong. It is interesting to note that none of the Realists' predictions were realized. On the contrary, never has there been more bilateral trade, economic, cultural, governmental and even peaceful military contact and exchange initiated between the United States and China. Apparently, the United States and China have their own valid reasons to nurture this relationship, among them; strategic factors were the major reason to bringing them together (Sutter, 1978, p. 118). This kind of "strategic needs" hence has deeply linked the United States and China since 1979 and has greatly promoted the development of their relations, despite. The occasional setbacks that have occurred.

If power politics and the democratic peace thesis cannot be used to better explain US-China relations in the past thirty years, then how about the theory of complex interdependence? If so, then how can it influence this relationship? This 
paper intends to examine the debates between realists and liberals on US-China relations since the end of the Cold War, with trade used as the primary case study to discuss and demonstrate the influence and effect of complex interdependence in this relationship. I will also use the findings of this research to predict a positive development of US-China relations.

\section{Debates on US-China relations since the end of the Cold War}

Since there have been many difficulties and disputes between the United States and China, Realists therefore predicted that a war would happen eventually between the two countries. Based on the theory of balance of power, Realists claimed that the United States and China can not and will not have a good relationship. The dissolution of the Soviet Union, along with the rapid rise of China as a major economic power in the world since the 1980's and early 1990's, seem to greatly enhance the argument made by Realists. They argued that China, being both a rising power and a socialist country, has already made itself a primary target of the United States. Their views gained credence after the occurrence of the Tiananmen Square incident, when China-U.S. relations reached a historical low point. Among the Realist arguments, the theory of a 'China Threat' has gained the most attention and has had important influence in the United States. (Herbert Yee and Ian Storey, 2002). The theory of the China Threat appeared in the beginning of the 1990's, with proponents claiming that China was a rising power and represented a source of regional and international instability due to the rapid development of the Chinese economy since 1978 (during which China achieved growth averaging $9.9 \%$ per year); its authoritarian political system; its growing military strength accompanied by intensified territorial disputes with some neighbors (primarily in the South China Sea), and the continuing confrontation with Taiwan. In addition, the Chinese government's fear of a political and economic collapse all but prevented it from maintaining a good relationship with America, hence making it an uncertain factor in the stability of world politics. However, despite the many disagreements and disputes in the past thirty years, no form of armed conflict has ever taken place. Rather, Sino-American relations have gradually progressed in a more positive direction, and the two countries have since become more and more interdependent. Bilateral trade, economic agreements, and even military and cultural exchanges are proliferating between the U.S and China, and see no sign of stopping any time soon, contrary to Realist predictions.

Despite differing from the Realists' emphasis on power politics and their pessimistic views on the future development of US-China relations, liberals have also rejected optimistic views based on the democratic peace thesis. According to the democratic peace thesis, democratic states are more peaceful than non-democratic states, and democratic states do not fight with one another. For Michael 
Doyle, the major reason for democratic peace is that democratic governments have to be responsible to their citizens, and if a war becomes too costly, they will lose elections. (Doyle, 1986, p. 80). In a democratic state such as the United States, the procedure of foreign decision-making regarding war is transparent, and people are as sensitive as the decision makers to the costs of war, while also possessing the power to debate publicly and influence governmental policy directly. In addition, Doyle considers that there is a common desire to resolve conflicts peacefully among democratic countries; this common belief requires they coordinate their relations through respect and cooperation to expand contacts. This common desire then causes finally the production of common interests. Since the actions of national decision makers are supervised and constrained by people and legislature, they have to consider the cost of using military force; that is the reason why democracies rarely fight each other, and is also why liberals advocate democracy. The United States and China adhere to different polities, political institutions and societal structures, but have yet to engage in armed conflict in the post Cold-War era. Even in serious crises and incidents such as in the cases of the Belgrade Embassy bombing in 1999 and the 2001 Hainan Island Incident, the two countries did not use force to resolve the issue. Conversely, by means of bargaining and diplomacy, they resolved their disputes peacefully. Since the end of the Cold War, not only has peace been maintained in this relationship but the two countries have also developed close and highly interdependent economic and trade relations. The democratic peace thesis apparently has its problems in explaining the development of US-China relations.

The pessimistic predictions and viewpoints suggested by realist's power politics and the democratic peace thesis seemed to be unable to provide a satisfactory explanation for the current state of peace between the U.S and China. If power politics and the democratic peace thesis cannot be used to explain the peaceful coexistence between China and the United States since the end of the Vietnam War, then perhaps the theory of complex interdependence can provide a more satisfactory explanation. This chapter therefore intends to examine the development of China-U.S. relations in the past thirty years and conclude with a discussion of the influences and effects of complex interdependence to China-U.S. relations.

\section{US-China relations in the eyes of scholars}

In the field of international relations, and even in the fields of international politics economy, and business, many scholars have performed long-term studies of Sino-US relations and explore the United States and; in Zachary Karabell's book Superfusion: How China and America Became One Economy And Why the World Depends On It, the author discusses the development of Sino-U.S relations in the past 20 years, as well as providing reasons that indicate how a positive 
relationship will promote future prosperity and international stability. He was optimistic that the rise of China will result in an economic connection with the U.S that is so intricate and deep that neither side can afford to lose it; Therefore, even if future trade friction between the two countries increases, any attempts at ceasing economic ties (i.e. trade sanctions) will be limited in terms of its negative effects, as neither side can afford such setbacks for any extended period. With the growing prosperity of China's comprehensive national strength, the US-China economic cooperation is expected to be the world's economic powerhouse. The United States and China need each other and depend on each other, and both sides must come to terms with this new economic model, especially the United States. This book discusses the Sino-American Economic integration and dependence from the angle of US-China relations, providing us with detailed information to understand the development of Sino-American relations, but because of the focus on the state-to-state interactions and exchanges, it does not specify the dependence of the U.S upon the relationship, nor does it offer solutions to current sources of conflict. How To Change, by Handel Jones, is another book that explores US-China relations, In the book, Jones describes his constant visits to China over the past 30 years, and through his frequent contact with the Chinese government or corporate executives, offers a unique personal view into China's economic system. In Jones' other work Chinamerica: the Uneasy Partnership That Will Change The World, he discusses the relationship while considering the growing U.S. recession and China's rapid robust growth, and demanded that the U.S. must quickly change. Many realists predicting a US-China conflict, however, have ignored an important fact, which is that the development of Sino-US relations are as much a result of private economic interests as they are a result of political ones; The governments of the U.S and China have little choice but to comply with the will of the market. Jones is particularly focused on several important conflicts and mutually beneficial areas, and analyzes the cause of power fortune in the United States and the shift in policy, history and habits. The point of the book is to put forward his observations on the Chinese economy while offering a prescription for improving the U.S. economy; China's economy benefits from a strong sense of national pride, which is aptly named "national capitalism" or "state capitalism". The author cites a number of the United States policies in desperate need of reform, and argues that the United States' goal should be to enhance its products and resolve the imbalance between imports and exports through the export balance of trade deficit. Jones believes the United States and China share a totally new and unique economic model, one that cannot be clearly defined by any one system. However, despite his praises, Jones does not shy away from noting the potential risk of cooperation with China, and urges the United States should be cautious in its high-stakes economic gambit. Another analysis written by John Miller White "Sino-US Relations Strategy Win-Win China-US road across the Zero-Sum Game," points out the enormous benefits of the two sides' cooperation at a small cost; In pursuit of the common 
interest of a peaceful $21^{\text {st }}$ century, the United States and China must be willing to revise their political stances and goals. The book also stated that the United States must abandon its view of the insularity of the Chinese threat; White's point of view as a whole is biased in favor of neoliberal institutionalism. Coauthored by Richard Rosecrance and of Gu Guoliang, the book Power and Restraint: the Shared Vision for the US-China Relationship, analyzes the issue in two distinct sections: the first section discusses Sino-US relations based on the transfer of power between China and the United States, then down through military interaction and economic analysis of China's soft power. The second part focuses on political differences existing between the two powers, including in Taiwan issue, arms control and cooperation between the two countries in the region. The book covers a wide range of aspects, and further details the controversial issues that set the two nations at odds. Margaret MacMillan, wrote Seize the Hour: When Nixon met Mao Zedong, which discussed the historic meeting in 1972 between U.S. President Richard Nixon and Chinese leader Mao Zedong in Beijing, which set the stage for future Sino-US relations.. Through detailed research of historical facts, and detailed character personality descriptions, the book completely reviews the process of ice-breaking between the two countries, as well as the international situation regarding US-China negotiations and the attempt to include the Soviet Union in a Sino-US-Soviet strategic triangle. However, MacMillan's work is mainly focused on reviewing history, and did not touch upon the present relations between the United States and the PRC.

\section{Complex Interdependent Theory}

Complex interdependence-the basic and most important research framework in Robert Keohane and Joseph Nye's work- is an analytical model proposed by Keohane and Nye in Power and Interdependence, which is used to describe an ideal type of world politics and seeks to challenge the Realist assumptions. It describes 'a world in which actors other than states participate directly in world politics, in which a clear hierarchy of issues does not exist, and in which force is an ineffective instrument of policy.' (Keohane, Nye 1998, p. 311). As a result of the deep development of interdependence in international relations, Keohane and Nye intend to construct a new hypothetical model that is completely different to that of Realism. Although they emphasize that the model of complex interdependence they suggested is merely an ideal type, they claim that it increasingly corresponds to reality in many parts of the world. Their ideal type of complex interdependence emphasizes three basic concepts: The development of multiple channels connecting societies, which can be inter-state, trans-governmental, and transnational; The absence of hierarchy among issues, which means that military security does not consistently dominate the agenda; and the minor role of military force. These 
three basic concepts are the most important components to the theory of interdependence based on the basic characteristics of sensitivity and vulnerability. They can also be seen as reflecting the new progress interdependence theory made in the late 1970 s and early 1980 s.

According to Keohane and Nye, contemporary world politics are characterized by the following features: 1 . Multiple Channels Connecting Societiesthese channels include informal ties between governmental elites or formal foreign office arrangements, informal ties among nongovernmental elites, and transnational organizations. These communication channels help states to talk and exchange views and opinions, 2. Absence of Hierarchy among Issues-As the agenda of interstate relationships is comprised of multiple issues which are not arranged in a clear or consistent hierarchy, military security no longer dominates the agenda. Any issues can be discussed on states' agenda, 3. Minor Role of Military Force-When complex interdependence prevails, governments will not use military force toward other governments within the region, although force may be important in these governments' relations with governments outside that region, or on other issues. Following the increase in close contact and interdependence between industrialized and pluralist states, the state's fears of being attacked have declined. The role of military force has also decreased, and is no longer a primary instrument of foreign policy. The fact of the matter is that the application of force is both costly and unpredictable in most situations, although Keohane and Nye do not completely reject the importance of military force. In an interdependent world, resorting to military force against an independent state with which one has a variety of relationships is highly unlikely, since such a violent course of action may rupture any mutually profitable relations. That is to say, the use of force often has costly effects on national interests outside of national security; therefore, even authoritarian countries may be reluctant to employ force to achieve economic objectives. Hence, this implies that when states' relations are complexly interdependent, war is unlikely to happen. Moreover, the likelihood of states' cooperation can be increased as complex interdependence provides an environment for peaceful and diplomatic solutions to any issues at hand.

This study argues that the development of China-U.S. relations is in accordance with the assumptions of complex interdependence. The main three characteristics can be easily found in this relationship, namely, the ones characteristic of the ideal world of complex interdependence. And that is the reason why peace can be maintained in this relation. This chapter therefore intends to demonstrate, firstly, that China-U.S. relations do develop and progress towards complex interdependence. That is, this study will examine the development of China-U.S. economic, social and governmental relations since 1989 and discuss the effect and influence of complex interdependence in the relationship. 


\section{Interdependent US-China Trade and Economic Relations}

Economic and trade relations are the most important aspects of China-U.S. relations as they are the major factors that strengthen the development of bilateral relations. When the United States and China established diplomatic relations in 1979, they signed a trade agreement granting each other the most-favored-nation (MFN) status; subsequently, the two-way trade developed and grew rapidly. China has taken important actions to open its foreign trading system and integrate itself into the world trading system. China is now the world's third-largest economy after the United States and Japan, with a nominal GDP of \$ 3.5 trillion (2007) when measured in exchange rate terms. It is also now the world's third-largest trading nation with $\$ 2.17$ trillion in imports and exports, following the USA and Germany. According to American statistics, the bilateral trade increased sharply from $\$ 17.8$ billion in 1989 to $\$ 386.7$ billion in 2007; growing by a factor of 22. ChinaUS bilateral trade accounted for $17.7 \%$ of China's total trade amount. The United States now is China's largest trading partner. The United States is also the largest export market for China, and its fourth-largest import supplier (Time, 2009, International Herald Tribune 2006, US-China Business Council, 2009).

For the United States, China is America's third-largest export market and also the fastest growing export market of the United States. In 2001, US exports to China were $\$ 19.2$ billion, it then rose to $\$ 65.2$ billion in 2007 ; the percentage change between 2001 and 2007 was 240\%. (Zweig, 2008, p. 19). Moreover, China has surpassed Canada as the United States' biggest import supplier. The United States chiefly exports electrical machinery, transportation equipment. China mainly exports electrical machinery, apparel, telecommunication equipment, and office machines to the United States. This also indicates that China has gradually shifted its export structure from labor-intensive products such as textiles, shoes, and toys to capital-intensive goods. Although the bilateral trade did serve American interests and support China's development strategy, China has become the USA's largest deficit trading partner. This deficit sharply increased and exceeded $\$ 266.3$ billion in 2008, making it a serious political issue in China-U.S. relations. Americans therefore criticized that the huge deficit was caused by China's unfair trade practices, which is why trade issues remain the most important but sensitive issues in China-U.S. relations.

China-U.S. trade reached a particularly high level of growth during two periods, the years after 1979, when they established formal diplomatic relations, and during the post-Cold War era. Although American and Chinese statistical data do not match completely, both sets of trading statistics indicate that the bilateral trade developed in a positive direction. All the data indicates that Sino-American economic and trade relations have developed substantially, and quite harmoniously, in the post-Cold War era. China is a major and important source of consumer goods and cheap products for the United States, whilst America is China's major 
provider of important resources and equipment. The preponderance of American high-technology plays an indispensable role in China's modernization.

In addition to trade exchange, American investment in China also increased sharply. After China adopted its "Open Door" policy in 1978, it received a huge amount of foreign direct investment (FDI) during the 1980s. Following the opening of its market and economic reforms, foreign investors were allowed to manufacture and sell a wide range of goods in China and establish wholly foreign-owned enterprises. Nowadays half of China's exports are produced by foreign-invested enterprises. Foreign direct investment has played an important role in China's domestic economy. In 2003, China was the biggest recipient of FDI in the world. In 2005, China received another $\$ 60$ billion, making for a cumulative total of $\$ 623.8$ billion.' FDI in China in 2007 was $\$ 75$ billion; it then increased to $\$ 92.4$ billion in 2008 according to Chinese Ministry of Commerce. The increase in foreign investment chiefly flows to the service sector which attracted $\$ 38.12$ billion of FDI. Among the major investors, the United States has been China's primary investor country since 1979 . The cumulative realized amount of US investment in China was $\$ 57.13$ billion since 1979 till January 2008, ranking the second biggest investor of China after Japan. (Zweig, 2009, p. 118, US Department of State, 2006).

All the data indicates that China-U.S. economic and trade relations have developed substantially, and quite harmoniously, in the post-Cold War era. Not only is China's immense market attractive to US enterprises, but as US investment in China grows steeply, Chinese enterprises are now attempting to enter the American market. Since the rise of China's economy, China initiated a "Go Global" policy in 2000, which enhanced its economic relations with the United States. According to the Chinese Chamber of Commerce in the United States, by the end of December 2002, China invested $\$ 720$ million in the United States, constituting $9 \%$ of China's total investment abroad. 681 Chinese companies were permitted by the Chinese government to do business there (China Chamber of Commerce, 2004). Chinese-invested companies mainly have been concentrated in New York, followed by Los Angeles, San Francisco, Chicago, Houston and Seattle. The majority of Chinese enterprises focus on selling manufactured products. Since the global financial crisis, China has emerged as a major investor in the world, particularly in mineral and energy resources. In 2007, China's outward FDI was $\$ 18.6$ billion, and later rose 1.8 times to $\$ 52.2$ billion in 2008 .

To conclude, China is a major and important source of consumer goods and cheap electronic products for the United States, while America is China's major provider of important resources and equipment. The preponderance of American capital and high-technology has played an indispensable role in China's modernization. Following China's formal acceptance into the World Trade Organization (WTO) in December 2001, it has gradually opened its insurance, banking, telecommunications and services markets. This certainly will further 
enhance and promote the development of China-U.S. bilateral trade and investment. Although some disputes arise from close trade contact and exchange, such as protection of intellectual property rights and textile problems, economic interdependence does alleviate political tensions and strengthen the development of China-U.S. relations.

\section{From strategic considerations towards complex interdependent relations}

The United States and China are two completely different countries, both in terms of ideology, history, and social institutions. In terms of political ideology, The Peoples Republic of China aligned itself with the Socialist ideals of the U.S.S.R upon its founding in 1949, while the U.S is a democratic country and the foremost Western superpower.. Naturally, the relations between the United States the leading country of the capitalist camp - and China on the eve of the Cold War were hostile and vitriolic, with hardly any form of diplomatic contact between them. This mutual enmity lasted for almost twenty years, until the PRC began to confront the same political pressures and security threats from the U.S.S.R that the U.S. faced. Thus, in order to address "strategic needs," both nations were forced to reconsider the current status of their relationship and their respective foreign policies. Therefore, they began to normalize their relations beginning in the late 1960's, and finally established formal diplomatic relations in 1979.

Unfortunately, the establishment of formal diplomatic relations did not signal a smooth normalization of relations. There were and still are many problems interfering in the development of better Sino-American relations; some problems are longstanding, while others are relatively new. To further complicate the issue, embarrassing diplomatic incidents have also occurred over the years. Although there is some dissent existing in China-U.S. relations, the need to realize common interests and to promote strategic cooperation, as well as the reality of interdependence, forces the two nations to maintain a stable relationship and resolve disputes by means of negotiation. If one looks at the history of the development of China-U.S. relations, one will find that their relations in the 1950s and 1960s were pretty much close to realist assumptions. Military force was the most usable and effective instrument during this period, and it seemed that war could happen easily between China and the United States at any time. Moreover, due to the opposition of the capitalist and socialist camps, state agendas and world politics were primarily driven by questions of military security. In addition, there was no official contact between China and the United States. Since their relations were hostile, the United States greatly opposed China's participation in world organizations. Therefore, at the time, international organizations did not and could not play an important role in China-U.S. relations. 
Following the Sino-Soviet split and the eventual rupture of their relations in 1969 , compounded with changes on the international stage in the 1970s, the relationship between the United States and China had a chance to be normalized. Under the mutual need for strategic cooperation to oppose their common enemy, the Soviet Union, China and the United States adjusted their policy toward each other and gradually restored diplomatic relations in the late 1970s. That is, this kind of rapprochement and cooperation derived from realistic political considerations. This study argues that it was a 'have to' choice for the United States and China, and thus is a case of power politics in play. National security was still the major issue the two nations were concerned about. Ever since the normalization of their relations, bilateral contact increased, and the likelihood of military conflict decreased. Although their relations during this period in time could not be completely characterized as "complex interdependence", the U.S and the P.R.C were at least better connected than in the early days of the Cold War, and were also progressing towards a closer interdependence.

Strategic needs greatly promoted the development of China-U.S. relations in the 1980s. Following the practice of China's "Open Door" policy and the establishment of formal diplomatic relations, official diplomatic contact along with private interchange between the United States and China increased sharply. Their interdependence was not limited to strategic cooperation any longer, but started to develop and extend to economic, trade, and cultural sectors. Sino-American relations gradually progressed toward complex interdependence. There are multiple channels connecting the two nations, allowing them to communicate and exchange views easily and smoothly with one another. Any issue can be discussed and talked about; military security issues do not dominate states' agenda any longer. Following the close contact and exchange, a highly interdependent relationship has formed; adopting military force to resolve disputes is not only unwise but also costly. Consequently, bargaining and consultation has become the major method for resolving problems.

As this study has examined and demonstrated in previous sections, in the case of China-U.S. relations, military security no longer overrides other issues; that is, it is no longer the dominant issue between the two nations. With the existence of multiple channels in states' relations, not only are transnational players starting to appear and pursue their own goals, trans-governmental politics also make their respective states' goals difficult to define. This situation is more apparent in the United States than in China, as China is still a socialist country, and is more capable of maintaining and pursuing coherent policies and goals. Regarding the instruments for achieving states' goals, military force still remains a potential instrument of state policy, despite the possible political ramifications that will inevitably follow. Conversely, one can clearly perceive that even under circumstances where force would normally be used,, the United States and China will always attempt to resolve their problems by means of negotiation first; 
whether it is through the exchange of trade contracts or the politicizing and linking of issues, both countries would indubitably prefer resolution through words rather than bullets.

In addition to inter-state contacts, trans-governmental and nongovernmental elites and trans-national organizations all participate actively in China-U.S. relations. Transnational actors and international organizations can potentially not only be major instruments of states' policy but also may intervene in states' interactions. Compared with the Cold-War era, their roles today are more apparent and outstanding and thus cannot be ignored. As there are many more actors intervening in China-U.S. relations than ever before, with each pursuing its own goals, state agendas are hence affected by numerous factors. In contemporary Sino-American relations, security threats are no longer the major factor in agenda change, while, economic concerns and issues have largely replaced them. Although not all of the characteristics of complex interdependence conditions are present in ChinaU.S. relations, they are closer and are progressing to the ideal world of complex interdependence, contrary to Realist assumptions.

\section{Conclusion}

Entering into the twenty-first century, the necessity for coordination in international affairs and cooperation in counter-terrorism all bring chances for the United States and China to work together. Although disputes have and will occur between the two nations, complex interdependence will push them to resolve problems peacefully and avoid armed conflict. That is, a more positive and optimistic future of the relationship can be expected. In sum, although the progress of China-U.S. negotiations on many issues may look like a long-term game of wrestling, it is a much better alternative to overt hostility. The past several decades have clearly demonstrated that despite China being a non-democratic country, it does not mean that amicable China-U.S. relations cannot be achieved, as the democratic peace supporters have claimed. However, this study predicts that with continued contact with other countries and rapid economic growth, a more open and democratic China can be expected. This chapter argues that realist assumptions cannot be applied to sufficiently describe and explain the development of China-U.S. relations in the post-Cold War era. Some Realists theories based on power politics claim that a war cannot be avoided in the end in China-U.S. relations, particularly on the sensitive Taiwan issue. Although the Taiwan issue remains a sensitive issue in US-China relations, I believe that the leaders of both sides, in the interest of their own citizens and economies, will abstain from making rash decisions and instead seek any and all peaceful solutions to the issue. It must be stressed that despite its virtues, complex interdependence is not a prerequisite for peace; however, events over the past several decades have indicated its positive influence on 
Sino-American relations, and assuming the leaders of the two nations continue to promote bilateral trade, inter-governmental exchange and mutual cultural understanding, long-term peace and prosperity should be easily achievable.

\section{References}

China Chamber of Commerce in the United States URL: <http://www.chinausbiz.com/id566.html> [accessed November 8, 2012].

David Zweig. (2008). "China and the World Economy: The Rise of a New Trading Nation". Paper presented at the World International Studies Association, Ljubljana: 19.

Herbert Yee and Ian Storey (eds.). (2002). The China Threat: Perceptions, Myths and Reality, London: Routledge,

Handel Jones. (2010). Chinamerica: the uneasy partnership that will changes the world. New York: McGraw-Hill.

International Herald Tribune. (2006). 'Jump in exports swells China's trade surplus'. URL: <http:// www.iht.com/articles/2006/04/11/bloomberg/sxsurplus.php> [accessed November 8, 2012].

John Milligan-Whyte. (2009). China and America's Emerging Partnership: A Realistic New Perspective. New York: SPI Books.

Mainland Affairs Council. URL: <http://www.mac.gov.tw/big5/statistic/em/182/29.pdf $>$ [accessed November 8, 2012].

Michael Doyle. (1986). "Liberalism and World Politics". American Political Science Review: 80.

Michael Doyle. (1997). Ways of War and Peace: Realism, Liberalism and Socialism. New York: Norton.

Richard Rosecrance and Gu Guoliang. (2009). Power and restraint: a shared vision for the U.S.-China relationship. New York: Public Affairs.

Robert G. Sutter. (1978). China-Watch: Toward Sino-American Reconciliation. Maryland: The Johns Hopkins University Press: 118.

Paul R. Viotti and Mark V. Kauppi (eds.). (2009). International Relations Theory: Realism, Pluralism, Globalism. $3^{\text {rd }}$ edn. Massachussetts: Allen and Bacon: 311.

Times Online. (2009). 'China now world's third-largest economy'. URL: <http://www.timesonline. co.uk/tol/news/world/asia/article5514156.ece> [accessed November 8, 2012].

US-China Business Council. (2009).'US-China Trade Statistics and China's World Trade Statistics'. URL: $<$ http://www.uschina.org/statistics/tradetable.html> [accessed November 8, 2012].

US Census Bureau' 'Trade with China: 2008'. URL: <http://www.census.gov/foreign-trade/balance/ c5700.html\#2008> [accessed November 8, 2012].

US Department of State. URL: <http://www.state.gov/r/pa/ei/bgn/18902.htm\#econ> [accessed November 8, 2012].

World Socialist Web Site. (2009). 'China emerges as a major exporter of capital'. URL: <http:// www.wsws.org/articles/2009/may2009/chin-m19.shtml> [accessed November 8, 2012].

Zachary Kar. (2009). Superfusion. New York: Simon \& Schuster Press. 